\title{
KOMUNIKASI INTERPERSONAL PASANGAN SUAMI ISTRI MELALUI TAARUF ONLINE DATING
}

\author{
Lucy Pujasari Supratman ${ }^{1}$, Permata Mardianti ${ }^{2}$ \\ ${ }^{1,2}$ Fakultas Komunikasi dan Bisnis, Program Studi Ilmu Komunikasi, Universitas Telkom \\ Jl. Telekomunikasi, Dayeuhkolot, Telp. (022) 70020000, Bandung, 40257 \\ No. Telp./HP: ${ }^{1} 081221524351,{ }^{2} 085694638495$ \\ E-mail: 1doktorlucysupratman@gmail.com, ${ }^{2}$ permamadianti@yahoo.co.id
}

Naskah diterima tanggal 3 Oktober 2016, direvisi tanggal 2 November 2016, disetujui tanggal 17 November 2016

\section{THE INTERPERSONAL COMMUNICATION OF SPOUSE THROUGH TAARUF ONLINE DATING}

\begin{abstract}
The development of social networking has revealed new opportunities for all varieties of internet sites that offer online dating services/online dating. One of them is the site of rumahtaaruf.com. During the process of matchmaking in rumahtaaruf.com, each candidate is accompanied by a mediator who acts as an intermediary for both parties. The job of mediator is to regulate and monitor the way of taaruf based on Islamic shari'a. This study focuses on the motive that underlying the attitudes of women and men who chosen spouses under the site services of rumahtaaruf.com. This study used a qualitative method with phenomenological approach. The data were obtained through interviews and observations. The informants were couples who have been married once brought together by rumahtaaruf.com administrator. The results showed that the motive prospective couples to choose rumahtaaruf.com was based on education, age, occupation, physical attraction, response of family and culture.
\end{abstract}

Keywords: interpersonal communication, taaruf online dating, motive.

\begin{abstract}
Abstrak. Perkembangan jejaring sosial telah membuka banyak peluang baru untuk beragam situs internet yang menawarkan layanan biro jodoh secara daring/online dating. Salah satunya adalah situs rumahtaaruf.com. Selama menjalani proses perjodohan di rumahtaaruf.com, setiap calon pasangan didampingi oleh satu mediator yang bertindak sebagai perantara kedua belah pihak. Peran mediator rumahtaaruf.com untuk mengatur serta memantau jalannya proses taaruf agar berjalan sesuai syariat Islam. Penelitian ini berfokus pada motif-motif yang mendasari sikap wanita dan pria memilih pasangan hidup menggunakan layanan situs rumahtaaruf.com. Penelitian ini menggunakan metode kualitatif dengan pendekatan fenomenologi. Data diperoleh melalui wawancara mendalam dan observasi. Informan penelitian ini adalah pasangan suami istri yang telah menikah setelah dipertemukan oleh administrator rumahtaaruf.com. Hasil penelitian menunjukkan bahwa motif calon pasangan suami istri memilih pasangannya di rumahtaaruf.com berdasarkan pendidikan, usia, pekerjaan, daya tarik fisik, respons keluarga, dan suku budaya.
\end{abstract}

Kata kunci: komunikasi interpersonal, taaruf daring, motif. 


\section{PENDAHULUAN}

Definisi komunikasi interpersonal mulai bergeser setelah hadirnya beragam media baru. Padahal, salah satu asumsi dari komunikasi interpersonal adalah para komunikannya saling bertatap muka. Mulyana (2008) menyatakan bahwa komunikasi interpersonal adalah komunikasi antara orang-orang, yang memungkinkan setiap pesertanya menangkap reaksi orang lain secara langsung, baik verbal maupun non-verbal secara tatap muka. Seiring berkembangnya teknologi internet, maka berubah pula cara berkomunikasi. Media baru juga sudah memiliki fitur-fitur tersendiri seperti line yang dapat melakukan video call atau dapat juga melalui skype. Data pengguna Internet menurut lembaga riset pasar $e$ Marketer, diperkirakan pada tahun 2018 mencapai 3,6 milliar di seluruh dunia (Yusuf, 2014).

Internet telah memberikan banyak implikasi guna membantu manusia di berbagai lini kehidupan untuk berbisnis, berpolitik, pendidikan, beriklan, hingga mencari pasangan. Peluang bisnis baru untuk membuka situs-situs yang menawarkan layanan biro jodoh secara daring atau biasa dikenal sebagai online dating. Aktivitas kencan online dapat dilakukan dengan bergabung dalam salah satu situs kencan online ataupun aktif menggunakan jejaring sosial. Lima situs kencan online yang paling sering diakses adalah meetup.com, match.com, okcupid.com, POV.com, dan adultfindfinder.com. Di Indonesia, ada beberapa situs kencan online yang terkenal dan memiliki ribuan pengguna, seperti setipe.com, jodohsakinah.com, indonesiancupid.com, ayonikah.com, dan masih banyak situs kencan online lainnya. Setiap situs kencan online memiliki karakteristiknya masing-masing dan target penggunanya. Tabel 1 memperlihatkan situs kencan online yang sering digunakan oleh pengguna internet di Indonesia

Tabel 1

Daftar Situs Kencan Online di Indonesia

\begin{tabular}{|c|c|c|c|}
\hline No & Website & Berbayar/Tidak berbayar & Keterangan \\
\hline 1 & setipe.com & Tidak berbayar & $\begin{array}{l}\text { setipe.com, situs ini dibuat oleh Razi } \\
\text { Thalib. Situs ini mencocokan } \\
\text { pasangannya berdasarkan hasil kecocokan } \\
\text { presentase dari tes psikologi saat } \\
\text { mendaftar. }\end{array}$ \\
\hline 2 & indonesiancupid.com & Tidak berbayar & $\begin{array}{l}\text { indonesiancupid.com merupakan situs } \\
\text { yang memiliki server di Australia. Situs } \\
\text { ini merupakan situs kencan online yang } \\
\text { memudahkan penggunanya untuk mencari } \\
\text { pasangannya di seluruh dunia. }\end{array}$ \\
\hline 3 & jodohsakinah. com & Berbayar & $\begin{array}{l}\text { jodohsakinah.com, merupakan situs biro } \\
\text { jodoh Islam online yang dilengkapi fitur } \\
\text { chatting, blogging, video, music, dan } \\
\text { pesan pribadi. Pengguna situs ini } \\
\text { diharuskan untuk membayar sejumlah } \\
\text { uang untuk mengakses situs tersebut. }\end{array}$ \\
\hline
\end{tabular}

4 ayonikah.com

Berbayar

5

rumahTaaruf.

com
Tidak berbayar ayonikah.com, merupakan situs kencan online yang mengharuskan penggunanya membayar. Situs ini diperuntukkan bagi pengguna yang siap menikah. Situs ini dilengkapi fitur webcam dan chat.

rumahtaaruf.com, merupakan situs taaruf online yang membantu anggotanya dalam mendapatkan jodoh dengan prosesi 




Sumber: Olahan Peneliti.

Berdasarkan Tabel 1, terdapat beberapa situs kencan online yang dapat diakses secara gratis dan penggunanya bebas memilih pasangan kencan online nya, seperti pada situs kencan online setipe.com, indonesiancupid.com, dan rumahtaaruf.com. Namun, ada juga situs kencan online yang mengharuskan setiap penggunanya untuk mendaftar dan membayar iuran pertahun seperti pada jodohsakinah.com, ayonikah.com, dan siapnikah.com. Hal ini untuk menghindari remaja di bawah umur dan orang-orang yang tidak bertanggung jawab mengakses situs tersebut. Seluruh situs online dating dari Indonesia dan luar negeri harus melakukan langkah negosiasi identitas untuk memudahkan pengenalan identitas diri. Semisal seorang pria dapat dengan mudah duduk di sebuah coffee shop bersama laptop yang terkoneksi internet, ia dapat mengunggah data diri, foto, dan harapan kriteria pasangannya. Kemudian, membiarkan situs online dating tersebut yang akan menyelesaikan tahapan perkenalan selajutnya. Aktivitas online dating semacam ini dapat menghubungkan individu ke individu lainnya tanpa terbatasi oleh ruang dan waktu.

Dari beberapa situs online di atas, terdapat satu situs kencan online yang melakukan perjodohan serupa namun memiliki keunikan tersendiri yaitu rumahtaaruf.com. Berdasarkan wawancara Wahyu, selaku admin dan moderator rumahtaaruf.com, ia menjelaskan bahwa taaruf online daring di rumah taaruf ini membantu masyarakat yang membutuhkan pendamping hidup untuk dicarikan pasangan secara Islami.
Menurut wawancara yang dilakukan dengan admin rumah taaruf, data update terakhir adalah 580 anggota laki-laki dan 1.380 anggota perempuan, namun tidak semuanya aktif. Status keanggotaan yang aktif tinggal 220 anggota laki-laki dan 720 anggota perempuan, sisanya non aktif karena telah menikah dengan sesama anggota rumahtaaruf.com, mengundurkan diri, menikah dengan calon dari luar rumahtaaruf.com, dan beberapa alasan lainnya. Dari 191 proses mediasi taaruf yang telah dijalani, tercatat 26 pasangan anggota yang telah menikah, 5 (lima) pasangan yang sedang melakukan proses taaruf, 11 pasangan yang tidak melanjutkan proses taaruf online, dan sisanya 149 masih menjalani proses taaruf online.

Tata cara mengikuti taaruf online di situs rumahtaaruf.com, anggota wajib mengirimkan biodatanya kepada admin rumahtaaruf.com melalui email. Kemudian biodata tersebut akan diberikan kepada calon pasangan. Apabila calon pasangan setuju, maka admin akan membuka sesi tanya jawab kepada kedua belah pihak. Jika cocok maka pasangan tersebut akan memasuki tahap taaruf offline. Pada tahap ini pasangan taaruf akan saling bertemu secara langsung dan bertukar informasi melalui perantara mediator. Mediator berfungsi sebagai orang yang mengatur proses jalannya proses taaruf agar sesuai prosedur taaruf. Kemudian, setelah pasangan melakukan proses taaruf offline maka dilanjutkan pada proses penentuan hubungan. Apabila hubungan berlanjut maka proses selanjutnya adalah lamaran dan menikah. Peran rumahtaaruf.com sudah tidak terlalu 
aktif lagi ketika pasangan menikah, namun pasangan yang sudah menikah akan terikat menjadi alumni rumahtaaruf.com dan mereka bisa menjadi mediator untuk pasangan taaruf selanjutnya.
Ada beberapa perbedaan antara rumahtaaruf.com dengan situs kencan online yang telah disebutkan di atas, antara lain seperti terlihat pada Tabel 2 .

Tabel 2

Perbedaan rumahtaaruf.com dengan Situs Kencan Online Lain

\begin{tabular}{|c|c|c|}
\hline No & rumahtaaruf.com & Situs kencan online \\
\hline 1 & $\begin{array}{l}\text { rumahtaaruf.com tidak mengenakan biaya bagi } \\
\text { anggotanya. }\end{array}$ & $\begin{array}{l}\text { Beberapa situs kencan online ada yang } \\
\text { berbayar dan ada yang tidak dikenakan biaya. }\end{array}$ \\
\hline 2 & $\begin{array}{l}\text { rumahtaaruf.com tidak memajang foto anggota } \\
\text { ataupun informasi yang bersifat privasi (alamat, } \\
\text { nomor telepon) secara terbuka di website. }\end{array}$ & $\begin{array}{l}\text { Situs kencan online memajang foto } \\
\text { anggotanya, bahkan diwajibkan mengupload } \\
\text { foto ketika melakukan registrasi. }\end{array}$ \\
\hline 3 & $\begin{array}{l}\text { rumahtaaruf.com tidak memperkenankan } \\
\text { komunikasi langsung antaranggota selama proses } \\
\text { taaruf dijalani, dan baru diperbolehkan apabila sudah } \\
\text { masuk tahap serius ke keluarga untuk memersiapkan } \\
\text { pernikahan. }\end{array}$ & $\begin{array}{l}\text { Situs kencan online memiliki fitur chat, private } \\
\text { message, dan webcam untuk memudahkan } \\
\text { anggotanya berkomunikasi langsung. }\end{array}$ \\
\hline 4 & $\begin{array}{l}\text { Komunikasi dilakukan sebatas mengirim email } \\
\text { melalui perantara dari rumahtaaruf.com Proses } \\
\text { taaruf offline harus didampingi moderator. }\end{array}$ & $\begin{array}{l}\text { Pemilik situs tidak menjadi perantara } \\
\text { penggunanya. Pemilik hanya sebagai penyedia } \\
\text { fasilitas dan fitur situs. }\end{array}$ \\
\hline 5 & $\begin{array}{l}\text { Tidak menggunakan sistem me } \\
\text { anggota hanya perlu mengirim bioc }\end{array}$ & $\begin{array}{l}\text { Menggunakan sistem member deng } \\
\text { nelakukan registrasi di website tersebut. }\end{array}$ \\
\hline
\end{tabular}

Sumber: Olahan Peneliti

Awal mula berdirinya rumah taaruf my Quran tidak terlepas dari keberadaan forum diskusi online my Quran. Diawali Tahun 2001 dengan nama sub forum perkenalan dan perjodohan yang merupakan salah satu bagian dari forum, pada Tahun 2004 berubah nama menjadi sub forum taaruf, pernikahan, dan jalin rumah tangga (Tahan Jaga) yang dijadikan sebagai fasilitas taaruf dan pencarian jodoh oleh anggota forum. Pada Tahun 2011 hingga akhir 2013 sub forum proses taaruf berubah nama menjadi sub forum taaruf dan jodoh.

Pada awal bulan Januari 2014 berdirilah rumah taaruf my Quran dengan alamat www.rumahtaaruf.com. Selama menjalani proses perjodohan di rumahtaaruf.com, setiap calon pasangan didampingi oleh satu mediator. Mediator adalah orang yang bertindak sebagai perantara kedua belah pihak. Saat ini sebanyak 25 pasang mediator rumahtaaruf.com yang telah tersebar di beberapa kota besar di Indonesia, seperti:
Jakarta, Bogor, Depok, Karawang, Cianjur, Bandung, Cirebon, Purwokerto, Yogyakarta, Surabaya, Medan, Padang, dan Balikpapan. Mediator dari rumahtaaruf.com merupakan pasangan anggota rumahtaaruf.com yang telah menikah.

Ada beberapa fungsi dan peran dari mediator rumahtaaruf.com, yaitu: mediator rumahtaaruf.com memiliki peran untuk mengatur dan memantau jalannya proses taaruf sehingga tetap berjalan sesuai syariat yang ada, mereka memiliki fungsi sebagai perantara komunikasi selama proses taaruf berjalan untuk menghindari ke-mudharat-an komunikasi langsung dan memiliki fungsi serta peran dalam memberikan nasihat apabila terdapat masalah pada kedua belah pihak calon pasangan selama proses taaruf berjalan. Penelitian ini menarik karena pasangan tidak berkomunikasi secara langsung melainkan mereka berkomunikasi dengan $e$-mail dan melalui perantara admin/mediator. Pasangan juga 
tidak diberi informasi kontak, apabila ingin menanyakan sesuatu harus melalui mediator. Selain itu, kekhasan dari konteks komunikasi interpersonal pasangan suami istri yang sebelumnya dipertemukan melalui situs rumahtaaruf.com merupakan situs perjodohan online dating berdasarkan sistem Islami taaruf masih jarang diangkat sebagai topik penelitian dalam penelitianpenelitian komunikasi sebelumnya.

\section{LANDASAN KONSEP}

\section{Komunikasi Interpersonal}

Komunikasi

interpersonal

melibatkan suatu bentuk aktivitas timbal balik (mutual activity), interaksi (interaction), atau pertukaran (exchange). Guerrero dalam Berger (2014), komunikasi interpersonal adalah pertukaran pesan di antara orang, dengan sebuah "pesan" menjadi perilaku orang lain, yang dimaksudkan atau tidak, dapat diinterpretasikan oleh seorang penerima tanpa batasan tentang jumlah orang yang terlibat pertukaran tersebut. Uraian tentang individu yang saling berkomunikasi dalam lingkungannya akhirnya menjadi media fardhu bagi manusia untuk menyampaikan idenya (Supratman, 2016). Maka di sinilah fungsi dari komunikasi interpersonal berada sebagai sharing ideas and knowledge antarmanusia. Menurut Berger (2014), komunikasi interpersonal tersusun dari banyak proses yang saling terkait, terdiri dari produksi pesan, pengolahan pesan, koordinasi interaksi, dan persepsi sosial. Produksi pesan adalah proses menghasilkan perilaku verbal dan perilaku nonverbal yang dimaksudkan untuk menyampaikan suatu keadaan batin kepada orang lain guna mencapai tujuantujuan sosial. Pengolahan pesan meliputi menginterpretasi perilaku dan implikasiimplikasi perilaku mereka. Koordinasi interaksi adalah proses menyelaraskan aktivitas produksi pesan dan pengolahan pesan sehingga menghasilkan pertukaran yang lancar dan koheren. Terakhir, persepsi sosial adalah kumpulan prosesproses yang dijalani untuk memaknai dunia sosial, termasuk menyelami diri sendiri, orang lain, hubungan sosial, dan pranata sosial. Aw (2011) mengasumsikan bahwa proses komunikasi interpersonal akan terjadi apabila ada pengirim menyampaikan informasi berupa lambang verbal maupun non verbal kepada penerima dengan menggunakan medium suara manusia (human voice) maupun dengan medium tulisan.

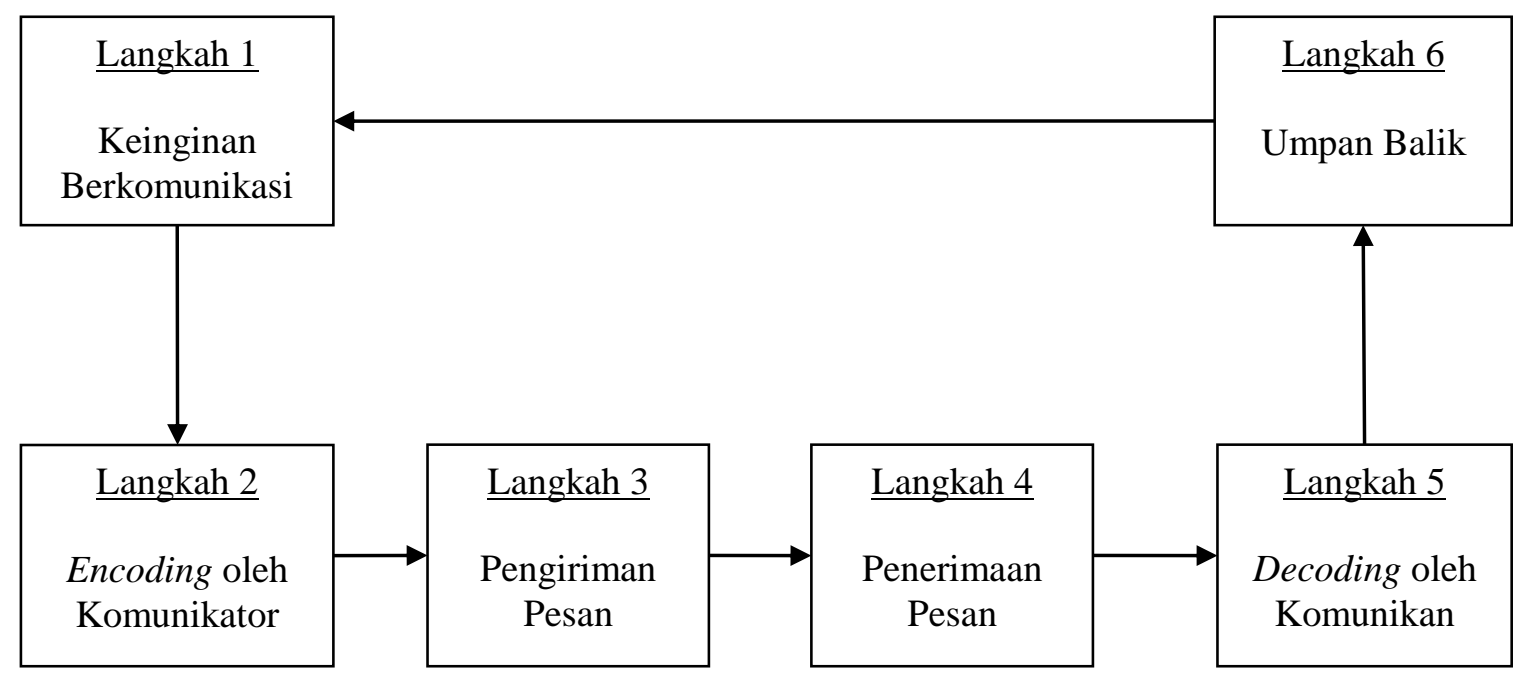

Sumber: Aw (2011)

Gambar 1. Proses Komunikasi Interpersonal. 
Gambar 1 menjelaskan mengenai proses komunikasi interpersonal yang diawali dari langkah pertama yaitu keinginan berkomunikasi. Keinginan berkomunikasi ini muncul berupa gagasan, informasi, opini, dan lain-lain yang ingin disampaikan komunikator. Langkah kedua yakni komunikator menyandi (encoding) pesan yang akan disampaikan kepada komunikan. Komunikator mampu membentuk pesan dalam lambang (bahasa) yang mampu dimengerti oleh komunikan. Langkah selanjutnya yaitu langkah ketiga di mana komunikator mengirimkan pesan yang ingin ia sampaikan kepada komunikan. Komunikan kemudian menerima pesan dari komunikator yang selanjutnya terjadi proses decoding dalam hal ini komunikan mengartikan makna dan lambang yang disampaikan oleh komunikator. Dari proses decoding itulah menghasilkan umpan balik (feedback) berupa tanggapan komunikan kepada komunikator, begitu seterusnya menjadi suatu siklus komunikasi. Dalam hubungan interpersonal, Devito (2011) menguraikan lima tahap dalam pengembangan hubungan. Kelima tahap ini adalah kontak, keterlibatan, keakraban, perusakan, dan pemutusan.

a. Kontak

Pada tahap pertama terjadi pembuatan kontak. Pada tahap ini terjadi pemutusan apakah hubungan ini berlanjut atau tidak. Pada tahap ini penampilan fisik begitu penting, karena dimensi fisik paling terbuka untuk diamati secara mudah. Meskipun demikian, kualitas-kualitas lain seperti sikap bersahabat, kehangatan, keterbukaan, dan dinamisme juga terungkap pada tahap ini.

b. Keterlibatan

Pada tahap keterlibatan adalah tahap pengenalan lebih jauh, ketika mengikatkan diri sendiri untuk lebih mengenal orang lain dan juga mengungkapkan diri.

c. Keakraban

Pada tahap keakraban terjadi pengikatan diri lebih jauh pada orang tersebut, komitmen pada tahap ini mempunyai berbagai bentuk seperti: perkawinan, membantu orang tersebut, atau mengungkapkan rahasia terbesar anda.

d. Perusakan

Pada tahap ini merupakan penurunan hubungan, ketika ikatan di antara kedua pihak melemah. Dan akan terasa bahwa hubungan tidaklah sepenting sebelumnya.

e. Pemutusan

Tahap pemutusan adalah pemutusan ikatan yang mempertalikan kedua belah pihak. Jika bentuk ikatan adalah perkawinan, pemutusan hubungan dilambangkan dengan perceraian.

Keluar

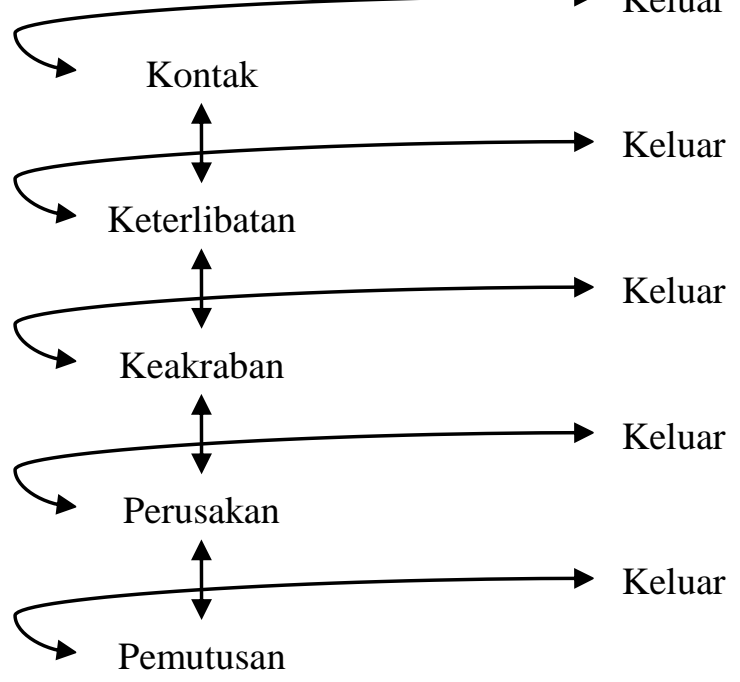

Gambar 2. Model Hubungan Lima Tahap (Devito, 2011) 
Devito (2011), mengatakan bahwa setiap hubungan bersifat unik. Begitu juga ketika membina hubungan karena alasanalasan yang unik. Empat alasan umum untuk pengembangan hubungan adalah mengurangi kesepian, mendapatkan rangsangan, mendapatkan pengetahuan diri, memaksimalkan kesenangan, dan meminimalkan penderitaan.

\section{a. Mengurangi Kesepian}

Kontak dengan sesama manusia mengurangi kesepian. Setiap individu memunyai kebutuhan akan kontak yang dekat, kadang secara fisik, adakalanya secara emosional, dan lebih sering keduanya.

b. Mendapatkan Rangsangan

Manusia membutuhkan stimuli. Kontak antarmanusia merupakan salah satu cara terbaik untuk mendapatkan stimuli. Manusia membutuhkan stimuli intelektual, stimuli fisik, dan stimuli emosional.

c. Mendapatkan pengetahuan diri (self knowledge)

Sebagian besar melalui kontak dengan sesama manusia tiap individu bisa memahami dirinya. Persepsi diri sangat dipengaruhi oleh apa yang dipikirkan orang lain.
d. Memaksimalkan
kesenangan, meminimalkan penderitaan

\section{METODE PENELITIAN}

Pada penelitian ini, penulis menggunakan pendekatan fenomenologi Alfred Schutz dengan paradigma konstruktivis. Littlejohn dan Foss (2009) berasumsi bahwa individu menafsir dan bertindak menurut kategori konseptual yang ada dalam pikiran. Manusia dituntut untuk saling memahami satu sama lain dan bertindak dalam kenyataan yang sama untuk mendapatkan kesamaan makna. Makna bukan sesuatu yang lahir di luar pengalaman objek penelitian atau peneliti, akan tetapi menjadi bagian terbesar dari kehidupan penelitian ataupun objek penelitian (Bungin, 2011). Natanson dalam Sobur (2013) menggunakan istilah fenomenologis sebagai istilah generik untuk merujuk pada semua pandangan ilmu sosial yang menempatkan kesadaran manusia dan makna subjektifnya sebagai fokus untuk memahami tindakan sosial. Dengan demikian ada penerimaan timbal balik, pemahaman atas dasar pengalaman bersama, dan tindakan atas dunia bersama. Pengalaman dan perilaku manusia dalam dunia sosial merupakan realitas yang bermakna secara sosial. Schutz menyebut manusia yang berperilaku tersebut sebagai 'aktor'.

Fenomenologi

Schutz menyimpulkan bahwa tindakan sosial berorientasi pada perilaku orang atau orang lain pada masa lalu, sekarang, dan akan datang. Untuk menggambarkan tindakan sosial tersebut, Schutz membaginya menjadi dua fase tindakan yaitu in order to motive, yang merujuk pada masa yang akan datang dan because motive yang merujuk pada masa lalu (Kuswarno, 2009).

Dalam konteks penelitian ini, pasangan rumahtaaruf.com adalah aktor yang melakukan tindakan sosial (mencari jodoh) bersama aktor lainnya sehingga memiliki kesamaan dan kebersamaan dalam ikatan makna intersubjektivitas. Mengikuti pendekatan Schutz, pasangan rumahtaaruf.com sebagai aktor mungkin memiliki motif yang berorientasi pada masa depan (in order to motive) dan motif berorientasi pada masa lalu (because motives).

Berdasarkan kriteria tersebut, maka informan dalam penelitian ini dipilih berdasarkan karakteristik berikut:

1. Perempuan atau laki-laki.

2. Anggota (pendaftar) situs rumahtaaruf.com

3. Sudah melalui proses taaruf online dan taaruf offline

4. Sudah menikah karena bertemu dari rumahtaaruf.com 
5. Usia $25-40$ tahun

6. Sudah menikah minimal 6 bulan atau 1 tahun.

Bersedia untuk diwawancara dan direkam aktivitasnya selama wawancara berlangsung. Menurut Moleong (2015), wawancara adalah percakapan dengan maksud tertentu. Percakapan itu dilakukan melalui wawancara mendalam (depth interview).

Tabel 3

Informan Peneliti

\begin{tabular}{clcl}
\hline No & \multicolumn{1}{c}{ Nama Pasangan } & Tahun Menikah & Lokasi \\
\hline 1 & Ardi dan Rini & 2015 & Depok \\
2 & Tommy dan Dena & 2014 & Bekasi \\
3 & Arif dan Ida & 2013 & Bekasi \\
\hline
\end{tabular}

Sumber: Olahan Peneliti

Penelitian ini menggunakan informan pendukung yaitu moderator sekaligus admin dari rumahtaaruf.com, Tri Wahyu Nugroho. Informan pendukung berfungsi sebagai pemberi informasi penegas pernyataan dari subjek penelitian.

Analisis data dalam penelitian kualitatif dilakukan pada saat pengumpulan data berlangsung, dan setelah pengumpulan data dalam periode tertentu. Pada saat wawancara, penulis sudah melakukan analisis terhadap jawaban yang diwawancarai. Bila jawaban yang belum diwawancarai setelah dianalisis terasa belum memuaskan, maka penulis akan melanjutkan pertanyaan lagi, sampai tahap tertentu diperoleh data yang dianggap kredibel (Sugiyono, 2016) .

Adapun langkah-langkah yang dilakukan dalam menganalisis data adalah sebagai berikut:

1. Data yang terkumpul dikategorikan dan dipilih menurut jenis datanya.

2. Melakukan seleksi data yang dianggap data inti dan berkaitan langsung dengan permasalahan serta data yang hanya merupakan data pendukung.

3. Menelaah, mengkaji, dan mempelajari lebih dalam data tersebut, kemudian melakukan pemaknaan terhadap data. Dalam proses pemaknaan penulis akan menjelaskan dan berargumentasi berdasarkan realitas yang terjadi kemudian mengonstruksinya.

\section{HASIL PENELITIAN DAN PEMBAHASAN}

Penelitian ini dilakukan sejak September 2015 sampai April 2016. Dalam enam bulan penelitian ini, peneliti melakukan wawancara terhadap tiga pasang suami-istri yang telah menikah setelah bertemu dan mengikuti proses di rumahtaaruf.com sebagai informan kunci dan satu informan pendukung yaitu moderator rumahtaaruf.com.

\section{Kriteria Memilih Pasangan}

Dari hasil wawancara, baik informan pria maupun wanita memiliki kesamaan kriteria yaitu berdasarkan pendidikan, pekerjaan, karakteristik pasangan, daya tarik fisik, respons keluarga, usia pasangan, dan keturunan atau suku.

\section{Usia Pasangan}

Hasil wawancara bersama keenam informan, mereka mengaku bahwa usia adalah kriteria yang mereka lihat ketika memilih pasangan. Tiga informan wanita cenderung memilih pria yang usianya lebih tua atau seumuran. Dalam curriculum vitae yang ditulis untuk rumahtaaruf.com memang terdapat tanggal lahir dan usia pria/wanita. Jumlah usia ditampilkan sebagai referensi seseorang dalam mencari pasangan. Pernyataan ini dibenarkan oleh pernyataan informan pendukung. Dua dari tiga pasangan informan yang diteliti yaitu 
pasangan Tommy dan Dena, serta pasangan Ardhi dan Rini memang memiliki perbedaan umur yang cukup jauh, sekitar lima - enam tahun. Sedangkan pasangan Arief dan Ida memiliki selisih umur satu tahun, di mana Ida lebih tua daripada Arief. Namun hal tersebut tidak berpengaruh ketika mereka memutuskan menikah. Bagi Arief dan Ida yang terpenting bukan masalah usia namun perihal kecocokan satu sama lain.

\section{Karakteristik Pasangan}

Faktor utama lainnya yang membuat individu yakin terhadap pasangannya adalah sifat atau karakteristik. Ketika membangun rumah tangga, mereka perlu mengetahui sifat atau karakteristik masingmasing. Uniknya dalam pasangan taaruf online ini pasangan belum mengetahui secara pasti sifat dari pasangan.

Mereka hanya menebak biodata pasangan dan dari tanya jawab yang mereka lakukan. Tommy mengaku awalnya ia melihat dari biodata pasangannya kemudian ia mengambil simpulan. Kemudian setelah ditanya alasan yang membuat Tommy menikah dengan pasangannya. Tommy menjawab, salah satunya adalah sifat pasangan yang nggak neko-neko. Tommy juga menceritakan jika awalnya ia mencari pasangan yang tidak perlu dibimbing, namun kemudian kriteria tersebut berubah dan ia menjadi mencari sosok yang mau dibimbing.

Selanjutnya pasangan Arief dan Ida mengaku jika ia melihat pasangannya berdasarkan dari sifatnya. Berdasarkan pernyataan Arief tersebut, maka bisa dikatakan jika Arief sangat memperhatikan sifat pasangannya. Begitu pula dengan pasangan Arief yaitu Ida. Bagi Ida kepribadian pasangan seperti emosi, merupakan salah satu faktor penting ketika memutuskan untuk memilih pasangan. Selain itu, Ida memang sengaja mencari pasangan keturunan suku Sunda, karena ia menganggap bahwa orang keturunan Sunda memiliki sifat yang baik.
Sedangkan Ardhi yang seorang duda mencari sosok perempuan yang lembut dan keibuan karena ia ingin pasangannya nanti bisa mendidik anaknya dengan baik dan mau menganggap anaknya sebagai anak sendiri. Lain lagi dengan Dena dan Rini yang mencari sosok pria yang mampu membimbing mereka dan memberikan mereka motivasi.

Menurut Dena sosok pendamping yang dia cari adalah sosok yang bisa membimbingnya ketika berumah tangga nanti. Sama halnya dengan Rini, menurutnya kriteria yang ia cari adalah kriteria laki-laki yang bisa membimbingnya secara bertahap saat berumah tangga. Dalam kategori karakteristik pasangan, perbedaan yang paling mencolok antara informan wanita dan informan laki-laki adalah informan wanita mencari sosok karakter laki-laki yang bisa membimbingnya dan bersifat dewasa. Sedangkan informan laki-laki mencari sosok karakter wanita yang mau dibimbingnya dan bersifat mandiri.

\section{Pendidikan}

Dari tiga pasangan informan, yang terdiri dari tiga laki-laki dan tiga perempuan ada yang memilih pasangannya berdasarkan pendidikan yang telah ditempuh. Tiga dari mereka memilih pasangan berdasarkan tingkat pendidikan dan jurusan kuliah, seperti yang dilakukan oleh Tommy, Arief, dan Rini. Tommy menceritakan bahwa ia memilih pasangan dengan latar belakang pendidikan minimal sarjana karena merupakan salah satu kriteria yang diinginkan orangtuanya. Jadi karena kriteria orangtua Tommy yang menginginkan menantu berpendidikan minimal sarjana, maka Tommy mencari pasangan yang juga seorang sarjana seperti dirinya. Dena yang menjadi pasangan Tommy adalah lulusan Sarjana Teknik salah satu universitas di Jakarta. Berbeda dengan Arief, dia memilih pasangannya karena aktif dalam kepengurusan masjid dan sering ikut kajian-kajian Islami di kampus. Lanjutnya Arief juga menilai 
bahwa perempuan yang aktif dalam kepengurusan masjid memiliki akhlak yang baik. Walaupun dia bukan seorang yang aktif dalam kepengurusan masjid. Rini melihat pasangannya dari latar belakang pendidikan dan juga sebagai 'promosi' kepada orangtuanya. Rini menambahkan ia memilih pasangannya berdasarkan jurusan kuliah dan organisasi semasa kuliah. Rini menceritakan sambil tertawa. Disebabkan latar belakang pendidikan pasangan yang baik membuatnya mudah mengenalkan pasangannya kepada orangtua.

Berdasarkan pernyataan para informan dapat disimpulkan bahwa pendidikan merupakan salah satu faktor penting yang dilihat para informan ketika memilih pasangan. Para informan wanita cenderung memilih pasangan pria yang memiliki pendidikan agama yang kuat seperti mengikuti rohis, alumni pesantren, ataupun lulusan perguruan tinggi Islam. Sedangkan informan laki-laki tidak terlalu melihat pendidikan, namun mereka paling tidak memiliki pasangan yang memiliki pendidikan yang setara dengan mereka, seperti minimal sarjana.

\section{Pekerjaan}

Salah satu kriteria yang sering dilihat oleh wanita ketika membaca biodata lakilaki dari rumahtaaruf.com adalah infromasi mengenai pekerjaan. Mereka cenderung ingin melihat apa pekerjaan calon pasangan mereka dan apakah pekerjaan tersebut pekerjaan tetap atau bukan. Pekerjaan pasangan akan berpengaruh kepada kehidupan finansial mereka setelah menikah, oleh karena itu salah satu kriteria yang sering dilihat wanita adalah jenis pekerjaannya. Informan pendukung juga menyatakan hal serupa.

Dari keseluruhan informan, dua orang informan wanita Dena dan Rini melihat pekerjaan pasangannya. Rini beranggapan bahwa pekerjaan Ardhi yang seorang wiraswasta cukup bagus sehingga membuatnya memilih Ardhi sebagai pasangan. Hal ini serupa dengan Dena yang ketika melihat biodata milik Tommy, ia sangat memerhatikan kolom pekerjaan Tommy.

Jika wanita melihat perkerjaan pria, berbeda dengan pria yang tidak melihat pekerjaan wanita, bahkan mereka meminta kesediaan pasangan mereka untuk berhenti bekerja dan menjadi ibu rumah tangga. Setelah menikah dengan pasangan masingmasing. Dena dan Rini yang sempat bekerja di salah satu perusahaan memutuskan untuk berhenti bekerja dan fokus untuk mengurus anak. Karena menurut informan pendukung pria sering bertanya pada pasangannya "Apakah si perempuan berencana tetap bekerja setelah menikah nanti atau memilih menjadi ibu rumah tangga saja". Hanya pasangan Arief dan Ida yang keduanya masih aktif bekerja setelah menikah.

\section{Respons Keluarga}

Ketiga pasangan informan, semuanya memiliki hubungan yang baik dengan orangtua pasangan masing-masing. Mereka bahkan menjelaskan bahwa dukungan dari orangtua pasangan masingmasing yang membuat mereka melangkah ke tahap berikutnya. Seperti pasangan Tommy dan Dena, pasangan ini mendapat tanggapan positif dari masing-masing keluarga. Tommy menceritakan bahwa Dena mendapatkan respons positif dari orangtuanya, khususnya ibunya. Orangtua Tommy menilai Dena adalah sosok perempuan yang baik dan manis. Alasan inilah yang membuat Tommy semakin yakin akan pilihannya. Dena yang diwawancarai bersama dengan Tommy menambahkan bahwa hubungan keluarga pasangan merupakan salah satu pertimbangan baginya.

Dia menganggap banyak pasangan yang tidak akur dengan mertuanya, maka dari itu ia menjadikan respons orangtua pasangan sebagai pertimbangan. Lain lagi dengan pasangan Arief dan Ida. Keluarga Arief sempat ragu dengan pasangan yang dipilih oleh Arief karena prosesnya 
melalui Internet yang dianggap negatif. Arief sempat menyayangkan sikap istrinya yang dulu tidak memberitahu orangtuanya jika dia mengikuti proses taaruf online.

Ida yang diwawancarai bersamaan membenarkan bahwa saat itu dia memang tidak memberitahu orangtuanya, namun setelah melewati proses taaruf offline barulah dia menceritakan kepada orangtuanya. Namun hal tersebut tidak menjadi masalah bagi orangtua Ida. Setelah dijelaskan orangtua Ida memberi respons positif terhadap pasangan yang dipilih Ida. Berbeda dengan pasangan Ardhi dan Rini. Ardhi yang sempat khawatir dengan tanggapan orangtua Rini terhadap statusnya yang seorang duda anak satu. Ardhi bahkan sempat bertanya pada Rini bagaimana pendapat orangtua Rini terhadapnya dan ternyata penilaian orangtua Rini postif. Rini menambahkan bahwa dari awal orangtuanya memang sudah tahu jika ia mengikuti proses taaruf online dan mereka memercayakan semuanya pada Rini. Maka dari itu orangtua Rini tidak mempermasalahkan status Ardhi yang seorang duda.

Ditanya perihal pendapat orangtua terhadap pasangan. Ardhi mengatakan bahwa yang membuat ia yakin terhadap pilihannya adalah dukungan dari ibunya. Ardhi mengaku bahwa memang ada tanggapan dari pihak keluarga almarhumah istrinya, tetapi ia tidak terlalu memikirkan pendapat dari keluarga almarhumah istrinya itu. Setelah melewati proses taaruf online maupun taaruf offline.

Kedua pasangan akan saling memperkenalkan diri pada keluarga masing-masing. Pada saat inilah respons keluarga menjadi penentu dalam hubungan mereka.

Respons keluarga yang positif menunjukkan bahwa pasangan mereka diterima dengan baik. Peneliti menyimpulkan, walaupun respons keluarga merupakan faktor eksternal dalam memilih pasangan namun faktor tersebut dianggap penting oleh pasangan informan.

\section{Daya Tarik Fisik}

Pasangan taaruf online awalnya diberikan biodata dan foto diri pasangan. Dari foto tersebut, individu bisa menilai dan merasakan ketertarikan walaupun mereka belum pernah bertemu sebelumnya. Mereka akan merasa senang apabila wajah yang mereka temui pertama kali sama dengan foto yang ada. Contohnya pasangan Ardhi dan Rini yang merasa senang karena persepsi mereka sama dengan foto.

Ardhi berpendapat bahwa wajah Rini yang ia lihat di foto dan wajah Rini ketika dilihat secara langsung ternyata tidak mengalami perbedaan. Ardhi berpendapat bahwa wajah Rini cantik. Sama halnya dengan Rini yang menganggap bahwa wajah Ardhi tidak jauh berbeda dengan yang ada di foto. Selain itu, ada Dena yang merasa bahwa pasangannya memiliki wajah yang mirip dengan wajahnya. Sedangkan Ida memang memiliki kriteria seputar kondisi fisik. Contohnya ia menginginkan pasangan yang memiliki tinggi badan lebih tinggi dari dirinya. Pria cenderung melihat wanita berdasarkan kondisi fisiknya.

Pernyataan ini didukung oleh penjelasan informan pendukung yang merupakan moderator ketika proses berlangsung. Kebanyakan, orang lebih menyukai yang memiliki fisik menarik daripada orang yang secara fisik tidak menarik, dan lebih menyukai orang yang memiliki kepribadian menyenangkan daripada yang tidak.

\section{Domisili Tinggal}

Sebagian informan masih memilih berdasarkan domisili tinggal. Alasannya karena mereka memikirkan faktor jarak. Contohnya Ardhi yang mencari orang yang tinggal di Pulau Jawa karena ia mencari yang dekat dengan tempat tinggalnya dan mudah terjangkau. Selanjutnya Arief yang mengatakan bahwa yang penting adalah domisili pasangan yang bisa dijangkau. Faktor suku menurut peneliti adalah faktor pendukung bagi 
pasangan ketika memilih. Menurut peneliti hal ini disebabkan karena wilayah tempat tinggal pasangan. Para pasangan cenderung memilih yang dekat daripada yang jauh, mengingat ketika proses taaruf offline mereka harus bertemu langsung. Apabila pasangan yang mereka pilih memiliki domisili yang jauh maka akan sulit untuk dijangkau.

Berbagai alasan yang mendorong informan memilih pasangannya dari rumahtaaruf.com telah disebutkan dalam hasil penelitian. Pada hasil penelitian, penulis menemukan bahwa kriteria pasangan menunjukkan orientasi masa lalu pasangan taaruf online dan cita-cita dan harapan pasangan menunjukkan orientasi masa depan pasangan taaruf online. Pada penelitian ini penulis membuat kategori baru yaitu motif masa kini. Motif masa kini menjelaskan alasan pasangan informan melakukan komunikasi interpersonal untuk memertahankan hubungan. Ketiga kategori motif tersebut melengkapi kajian fenomenologis Schutz tentang alasan seseorang melakukan suatu tindakan. Schutz mengatakan sulit untuk menemukan motif dari seseorang secara pasti. Untuk mengidentifikasi motif tersebut perlu dibuat suatu fase historis, yaitu masa lalu dan masa depan. Schutz menyebut because motive untuk menunjukan fase motif pada masa lalu, dan in order to motive untuk menunjukkan fase motif pada masa akan datang.

- Motif Masa Lalu, pada pasangan informan merupakan alasan mereka memilih pasangan tersebut. Mereka cenderung melihat latar belakang pasangan, misalnya para informan wanita mencari sosok yang serius, beragama kuat, dan memiliki sifat pemimpin karena pada masa lalunya mereka pernah menjalin hubungan namun gagal dan menyebabkan mereka mencari pasangan melalui taaruf online karena tidak ingin mengalami kejadian serupa. Sedangkan para informan pria cenderung memilih wanita yang berusia lebih muda, berakhlak baik, dan melihat kondisi fisik.

- Motif Masa Kini, pada pasangan informan ditemukan bahwa komunikasi yang terjalin setelah mereka menikah dan hubungan sebagai suami istri menjadi alasan tindakan mereka setelah menikah. Komunikasi yang mereka lakukan setelah menikah lebih bersifat terbuka, saling memahami, memperhitungkan visi misi ke depan sebagai suami istri. Mereka mulai mendekatkan diri satu sama lain agar kehidupan rumah tangga mereka sesuai dengan yang mereka harapakan. Pasangan taaruf memiliki jangka waktu yang pendek dari awal mereka berkenalan hingga menikah, apalagi awalnya mereka tidak saling mengenal satu sama lain. Maka, segala tindakan yang dilakukan meliputi interaksi dan komunikasi setelah menikah menjadikan motif masa kini untuk mereka.

- Motif Masa Depan, meliputi harapan dan cita-cita pasangan informan yang timbul setelah mereka menikah. Harapan dan cita-cita tersebut ada karena mereka memiliki motif masa kini yang sama. Dari motif masa kini maka para pasangan informan memiliki motif masa depan yang serupa juga seperti kehidupan rumah tangga yang sesuai agama, misalnya membangun rumah tangga yang mandiri, membuat program-program untuk mendekatkan diri pada Tuhan dan memikirkan hal-hal yang dapat mendekatkan diri satu sama lain. Selain itu mereka juga memikirkan kondisi ekonomi rumah tangga, misalnya mereka membeli rumah, kendaraan, dan pergi haji/umroh. Para pasangan informan sudah memiliki anak sehingga mereka mulai memikirkan masa depan sang anak, misalnya mereka menginginkan anak yang hafal Al Quran, ingin pendidikan yang terbaik, dan ingin menjadi 
orangtua yang mampu mendidik anak dengan baik.

Berdasarkan dari hasil motif masa lalu, motif masa kini, dan motif masa depan yang penulis dapatkan. Penulis meringkasnya menjadi sebuah model motif pasangan taaruf online. Model tersebut hubungan antara motif masa lalu, motif masa kini, dan motif masa depan, seperti terlihat pada Gambar 3

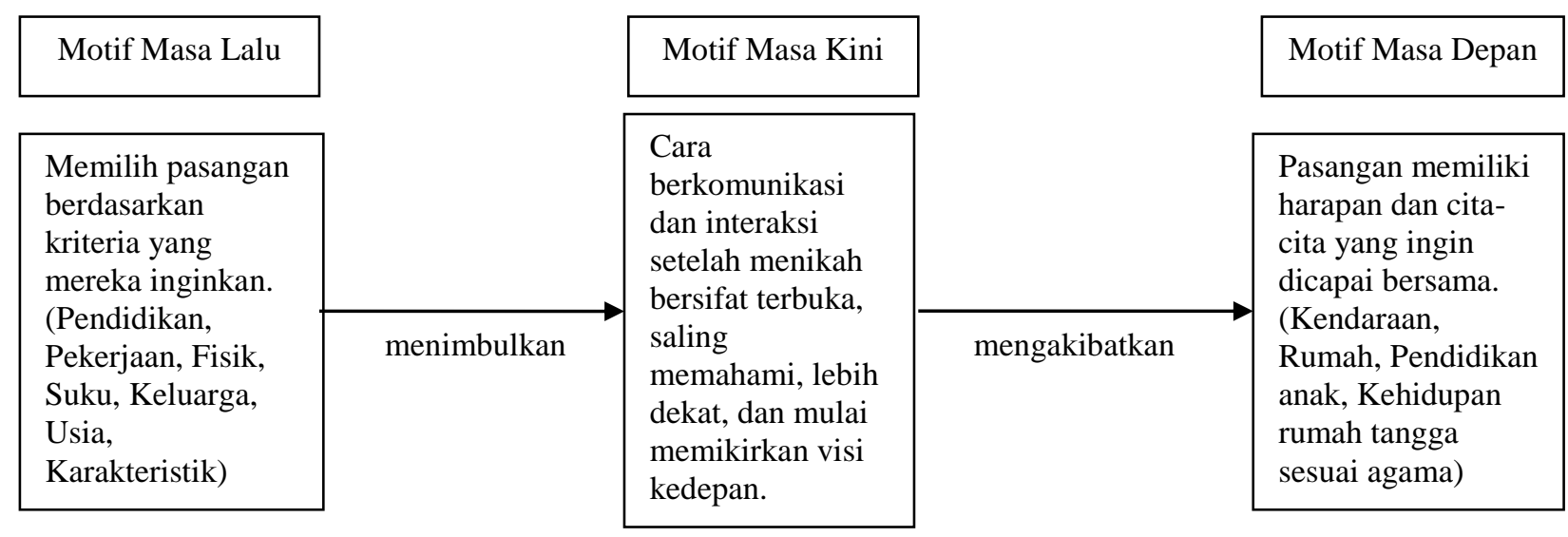

Gambar 3. Model Motif Pasangan Taaruf Online

Berdasarkan teori interaksionisme simbolik yang menilai bahwa aktor akan terlebih dahulu memahami dan menafsirkan stimulus tersebut untuk di respons dalam bentuk tindakan. Pada penelitian ini, pasangan taaruf online dating berperan sebagai aktor yang memilih, menilai, dan mengevaluasi terhadap tindakan yang akan, sedang, dan yang telah dilakukan.

Di satu sisi, teori interaksionisme simbolik meyakini realitas sosial tidak lepas dari interaksi aktor dengan menggunakan simbol-simbol. Pada penelitian ini simbol yang dimaksud adalah penggunaan bahasa untuk memunculkan makna melalui interaksi sosial. Menurut pendapat peneliti, para pasangan informan menggunakan simbolsimbol tersebut untuk berkomunikasi dengan aktor yang lain.

Sebagai contoh, para pasangan informan awalnya bertindak berdasarkan informasi yang mereka tahu, kemudian ketika mereka saling bertemu akan ada stimulus yang datang. Kemudian stimulus tersebut lebih dahulu dipahami dan ditafsirkan sebelum direspons dalam bentuk tindakan.

Oleh karena itu kebanyakan dari pasangan informan mengaku merasa canggung dan kaku ketika mereka berinteraksi pertama kali. Menurut pendapat peneliti, hal ini karena hasil interpretasi mereka terhadap satu sama lain.

Selanjutnya ketika para pasangan menikah akan semakin banyak penggunaan bahasa di kehidupan mereka sehari-hari, inilah yang mengakibatkan perubahan perilaku mereka. Para pasangan informan sudah lebih mampu menafsirkan dan memahami simbol-simbol agar bisa saling menyesuaikan tindakan mereka. Jika dulu mereka mengaku komunikasi yang mereka lakukan canggung dan kaku, maka setelah mereka saling menyesuaikan tindakan komunikasi yang terjadi lebih terbuka dan santai.

Penyesuaian tindakan dalam sisi komunikasi inilah yang menurut penulis menimbulkan motif masa kini tiap pasangan. 


\section{PENUTUP}

\section{Simpulan}

Website rumahtaaruf.com merupakan biro jodoh atau kencan online yang menggunakan prinsip Islami kepada para penggunanya. Para pasangan yang menggunakan website rumahtaaruf.com harus melewati proses taaruf online yang melibatkan moderator. Tentunya para pasangan dari rumahtaaruf.com memiliki perbedaan dengan para pasangan pada umumnya karena mereka tidak diizinkan untuk berkomunikasi secara langsung sebelum proses lamaran.

Para pasangan yang bertemu di rumahtaaruf.com memiliki motif masingmasing, mulai dari motif memilih pasangan hingga motif masa depan yang diharapkan bersama pasangan.

Para pasangan memiliki motif masa lalu, motif masa kini, dan motif masa depan. Motif masa lalu berkaitan dengan orientasi masa lalu para pasangan, motif masa kini berkaitan dengan orientasi saat ini, dan motif masa depan berkaitan dengan orientasi masa depan bersama pasangan. Selain itu perbedaan komunikasi sebelum dan sesudah menikah terjadi karena pengembangan hubungan interpersonal tiap pasangan taaruf online.

\section{Saran}

Pencarian jodoh melalui website online dating masih sering dianggap masyarakat sebagai wadah bagi para pria dan wanita yang telah mengalami keputusasaan dalam menjalin kasih. Namun, banyak situs yang menawarkan layanan pencarian jodoh secara Islami dan mayoritas para anggotanya memang ingin menjauhi berpacaran yang dilarang oleh agama. Wesbiste taaruf online dating yang bernama rumahtaaruf.com. Fenomena maraknya layanan online dating berbasis Islam adalah sebuah terobosan baru dalam kajian new media dan ilmu komunikasi. Pengembangan riset komunikasi dalam situs-situs online dating lainnya akan dapat memberikan pengayaan dalam literatur komunikasi di dunia cyber media.

\section{DAFTAR PUSTAKA}

Aw, S. (2011). Komunikasi Interpersonal. 1st ed. Yogyakarta: Graha Ilmu.

Berger, C. R. (2014). Handbook Ilmu Komunikasi. Bandung: Nusamedia.

Bungin, B. (2011). Penelitian Kualitatif. Jakarta: Kencana Prenada Media Group.

Devito, J. A. (2011). Komunikasi Antar Manusia. 5th ed. Tangerang: Karisma Publishing Group.

Kuswarno, E. (2009). Fenomenologi. Bandung: Widya Padjadjaran.

Littlejohn, S. W. and Foss, K. A. (2009). Teori Komunikasi: Theories of Human Communication. 9th ed. Jakarta: Salemba Humanika.

Moleong, L. J. (2015). Metodologi Penelitian Kualitatif. Bandung: PT. Remaja Rosdakarya.

Mulyana, D. (2008). Ilmu Komunikasi : Suatu Pengantar. Bandung: Remaja Rosdakarya.

Sobur, A. (2013). Filsafat Komunikasi Tradisi Fenomenologi. Bandung: PT. Remaja Rosdakarya.

Sugiyono. (2016). Metode Penelitian Kuantitatif, Kualitatif, dan $R \& D$. Bandung: Alfabeta.

Supratman, L. P. (2016). STUDI KASUS TENTANG KOMUNIKASI KESEHATAN PADA HUBUNGAN INTERPERSONAL TERAPIS DAN PASIEN DI PUSAT PENGOBATAN ALTERNATIF ATFG ARCAMANIK, BANDUNG. Lingkar Studi Komunikasi (LISKI), 2 (1).

Yusuf, O. (2014). Pengguna Internet Indonesia Nomor Enam Dunia. Kompas.com. [Online]. Available at: http://tekno.kompas.com/read/2014/11/2 4/07430087/Pengguna.Internet.Indonesi a.Nomor.Enam.Dunia. 